\title{
A forgotten scorpion: the identity of Buthus flavicruris Rainbow, 1896 (Scorpiones), with notes on Urodacus manicatus (Thorell)
}

\author{
Mark S. Harvey and Erich S. Volschenk \\ Department of Terrestrial Invertebrates, Western Australian Museum, \\ Francis Street, Perth, Western Australia 6000 , Australia
}

William J. Rainbow (1856-1919), whilst entomologist at the Australian Museum, Sydney, published a series of papers on the arachnid fauna of Australia and nearby regions. By modern standards these papers are generally imperfect but, to his credit, Rainbow illustrated the somatic and genitalic features of many of these species, a custom which was not yet firmly established amongst his contemporary arachnologists. One of these papers (Rainbow, 1896) contained the description of a new species of scorpion, Buthus flavicruris Rainbow, based upon a specimen collected from Cooma, New South Wales. This species was not cited by Koch (1977) or Fet et al. (2000), and appears to have been completely overlooked since the publication of the paper. The specimen cannot be found amongst the collections of the Australian Museum, Sydney (Mr G. Milledge, pers. comm.), and is considered lost.

Rainbow's (1896) figures, although somewhat rudimentary, clearly demonstrate that the species is not a member of the genus Buthus, or even of the Buthidae, but of a species of Urodacus (Urodacidae). The only Urodacus species found in that part of south-eastern Australia is U. manicatus (Thorell), which was redescribed and illustrated by Koch (1977). The description and illustrations of $B$. flavicruris match those of $U$. manicatus moderately well, although Rainbow's (1896) illustration of the metasoma of B. flavicruris (Rainbow, 1896, figure 4a) shows slightly more strongly developed dorsal keels than those of $U$. manicatus illustrated by Koch (1977). This discrepancy is probably due to Rainbow's sketchy style of illustration, rather than any real differences within the Cooma population. The dimensions quoted by Rainbow are well within the range of variation found in $U$. manicatus, as is the number of pectinal teeth - 16which indicates that Rainbow's specimen was probably a male.

We have no hesitation in placing $B$. flavicruris as a synonym of $U$. manicatus (new synonymy), despite the slight discrepancies between the published illustrations as noted above.

Urodacus manicatus is widespread throughout south-eastern Australia, ranging as far north as southern Queensland and as far west as the Flinders Ranges, South Australia. Although $U$. manicatus has been recorded twice from Western Australia, we consider these records to be incorrect. Pocock (1891) suggested that the two specimens from Western Australia described by Keyserling (1885) under the name $U$. novaehollandiae Peters were misidentified, and he proposed the name $U$. keyserlingii for the specimens. He later (Pocock, 1893) placed $U$. keyserlingii in the synonymy of $U$. abruptus. If this synonymy is correct, then we doubt the locality given for Keyserling's specimens.

The only other record of $U$. manicatus in Western Australia is that by Harvey (1981) from Madura. However, reexamination of these specimens shows that they represent $U$. novaehollandiae, a species which is commonly found along the southern edge of the Nullarbor Plain (Koch, 1977).

We therefore consider that $U$. manicatus does not occur in Western Australia, and is restricted to south-eastern Australia as depicted by Koch (1977). Urodacus manicatus - under the name $U$. abruptus Pocock - has been the subject of ecological and behavioural studies (Smith, 1966; Southcott, 1955), making it one of the better known of all Australian scorpions. It is commonly found on the slopes of the southern highlands of New South Wales and Victoria where it constructs shallow burrows under rocks and, less often, under logs (Smith, 1966). We here provide the primary synonymy of the species, based upon the list provided by Fet $e t$ al. (2000).

\section{Urodacus manicatus (Thorell)}

Ioctonus manicatus Thorell, 1876: 14-15. Type locality: Australia (as "New Holland").

Urodacus abruptus Pocock, 1888: 174-175, figs 4, 4a. Type localities: Adelaide, South Australia; and Australia (as "New Holland").

Urodacus keyserlingii Pocock, 1891: 245. Type locality: Western Australia, but probably incorrect (see above).

Buthus flavicruris Rainbow, 1896: 634. Type locality: Cooma, New South Wales. New synonymy. 


\section{REFERENCES}

Fet, V., Sissom, W.D., Lowe, G. and Braunwalder, M.E. (2000). Catalogue of the scorpions of the world (17581998). New York Entomological Society: New York.

Harvey, M.S. (1981). Urodacus manicatus (Thorell) (Scorpionida) in Western Australia. Australasian Arachnology 6: 3.

Keyserling, E. (1885). Ordo Scorpiones. In L. Koch and E. Keyserling, Die Arachniden Australiens, vol. 2: 1-39. Bauer and Raspe: Nürnberg.

Koch, L.E. (1977). The taxonomy, geographic distribution and evolutionary radiation of Australo-Papuan scorpions. Records of the Western Australian Museum 5: 83-367.

Pocock, R.I. (1888). The species of the genus Urodacus contained in the collection of the British (NaturalHistory) Museum. Annals and Magazine of Natural History (6) 2: 169-175.

Pocock, R.I. (1891). Notes on some scorpions collected by Mr. J.J. Walker, with descriptions of two new species and a new genus. Annals and Magazine of Natural History (6) 8: 241-247.

Pocock, R.I. (1893). Notes on the classification of scorpions, followed by some observations upon synonymy, with descriptions of new genera and species. Annals and Magazine of Natural History (6) 12: 303-330.

Rainbow, W.J. (1896). Contributions to a knowledge of the Arachnidan fauna of Australia. No. 1. Proceedings of the Linnean Society of New South Wales 1896: 634636.

Smith, G.T. (1966). Observations on the life history of the scorpion, Urodacus abruptus Pocock (Scorpionida) and an analysis of its home sites. Australian Journal of Zoology 14: 383-399.

Southcott, R.V. (1955). Some observations on the biology, including mating and other behaviour of the Australian scorpion Urodacus abruptus Pocock. Transactions of the Royal Society of South Australia 78: 145-154.

Thorell, T. (1876). On the classification of scorpions. Annals and Magazine of Natural History (4) 17: 1-15.

Manuscript received 12 February 2001; accepted 30 August 2001. 